\title{
TUGAS DAN TANGGUNGJAWAB GURU SEKOLAH MINGGU TERHADAP MASA DEPAN GEREJA
}

\author{
Hasudungan Simatupang \\ ${ }^{1)}$ Institut Agama Kristen Negeri Tarutung
}

\begin{abstract}
The purpose of this study was to determine the role of Sunday school teachers in organizing a series of learning processes not just the responsibility of filling free time on Sundays. This type of research is qualitative, using devotional theological research methods trying to apply the meaning of discourse to the reader's personal life without being separated from the learning objectives. The results of this qualitative research show the role of Sunday school teachers in preparing the ecclesiastical generation through the learning process as an effort to foster a generation of Christian churches from an early age. The tendency to use the learning method used, namely participatory fun, is very suitable for children, it can be followed through prayer, spiritual chanting, alphabeticism, followed by psychomotor (physical) movements in interpreting the discourse of a number of previously set learning objectives. The children were very loved by God, and the children showed enthusiasm to praise God, they were very excited in a cheerful atmosphere following the fun learning process. Thus it can be concluded how important the role of Sunday school teachers is to prepare the Christian church generation from an early age according to God's will.
\end{abstract}

Keywords: Sunday school teacher, Church

\begin{abstract}
ABSTRAK
Tujuan penelitian ini untuk mengetahui peran guru Sekolah Minggu menyelenggarakan serangkaian proses pembelajaran tidak sekedar tanggung jawab mengisi waktu senggang pada hari minggu Jenis penelitian ini kualitatif, menggunakan metode penelitian teologis devosional berusaha menerapkan makna wacana pada kehidupan pribadi pembaca tanpa dapat dipisahkan dari tujuan pembelajaran. Hasil penelitian kualitatif ini memperlihatkan peran guru Sekolah Minggu mempersiapkan generasi gerejawi melalui proses pembelajaran sebagai upaya pembinaan generasi gereja Kristen sejak dini. Kecenderungan pemanfaatan metode pembelajaran yang digunakan yakni partisipatif menyenangkan sangat cocok bagi anak-anak, dapat diikuti melalui doa, nyanian rohani, mengabjad, diikuti gerakan-gerakan psikomotorik (fisik) dalam memaknai wacana sejumlah tujuan pembelajaran yang ditetapkan sebelumnya. Anak-anak sangat disayangi Tuhan, dan anak-anak menunjukkan antusiasme memuji Tuhan sangat bergelora dalam suasana riang gempita mengkuti proses pembelajaran menyenangkan. Dengan demikian disimpulkan betapa pentingnya peran guru sekolah minggu mempersiapkan generasi gereja Kristen sejak dini sesuai kehendak Tuhan.
\end{abstract}

Kata Kunci: Guru Sekolah Minggu, Gereja 


\section{PENDAHULUAN}

Topik tentang "Tugas dan tanggungjawab Guru Sekolah Minggu Terhadap Masa Depan Gereja" merupakan tema menarik untuk digeluti bersama baik sebagai umat Kristen pada khususnya, maupun sebagai bangsa-bangsa pada umumya. Tugas dan tanggungjawab ini merupakan kewajiban bersama seluruh umat Kristen mempersiapkan generasi penerus memiliki masa depan lebih siap menjadi ahli waris gereja. Topik pembahasan ini menarik untuk digeluti, namun terlalu luas cakupannya. Untuk itu, tanpa mengurangi kandungan maka di dalamnya, perlu dilakukan usaha mempersempit scope dan countent di sekitar tugas dan tanggungjawab guru sekolah minggu mempersiapkan masa depan anak sekolah minggu sehingga kelak menjadi generasi penerus gereja Kristen di Indonesia.

Bagaimana kualitas pelayanan sedang dilakukan di Sekolah Minggu masa kini? Apakah pelayanan itu sudah cocok atau relevan? Untuk menjawab pertanyaan itu, pada dasarnya guru sekolah minggu terpanggil komit melayani, melakukan pembinaan sesuai fase-fase usia, agar kelak anak-anak Sekolah Minggu menjadi ahli waris gereja Kristen memiliki kualitas life skill (bertahan hidup) dan bertanggungjawab.

Abraham mengatakan: Tuhan, "Engkau tidak memberikan kepadaku keturunan, sehingga seorang hambaku nanti menjadi ahli warisku." (Kej. 15:3) dan Rasul Paulus mengatakan kepada jemaat di Efesus bahwa orang-orang bukan Yahudi, karena berita Injil, turut menjadi ahli-ahli waris dan anggota-anggota tubuh dan peserta dalam janji yang diberikan dalam Kristus Yesus (Efesus 3:6). Kedua nats ini memperlihatkan betapa perlunya guru sekolah minggu mempersiapkan pisik dan phisikis anak-anak. Berdasarkan pemikiran di atas, maka sejak dini perlu mempersiapkan anak-anak menjadi ahli waris berkulaitas, benar-benar memiliki kecerdasan spiritual dan intelektual termasuk kesadaran mutlak di dalam kehidupan bergereja di Indonesia.

Guru sekolah minggu senantiasa berusaha mengaktualisasi relevansi berbagai sumber-sumber informasi sebagai bahan-bahan komunikasi paedeya dalam pembelajaran, menyajikan sejumlah tujuan pelajaran sistemik, metodologis, dan paedagogis, bahkan diwajibkan memiliki sumber-sumber kajian akademis dalam melaksanakan kegiatan pembelajaran sehingga proses belajar mengajar berlangsung berkualitas, sama seperti Yesus berusaha menjadi Guru walaupun berkuasa dan Tuhan diakui tidak ada tandingan, tetap melakukan tugas mendidik dan mengajar melalui berbagai pendekatan akademis metodologis dan paedagogis, seiring mempersiapkan capability murid-murid kedua belas bertanggungjawab secara penuh, utuh dan dewasa. 


\section{PEMBAHASAN}

Pendidikan sekolah minggu pada awalnya tidak merupakan usaha gereja, melainkan usaha itu berasal dari kaum awam. Pendiri sekolah mingu "Robert Raikes" hidup pada akhir abad ke-18 sampai permulaan abad ke-19. Beliau seorang wartawan dan penerbit sebuah harian di Inggris memberi kontribusi penting memperhatikan masalah pendidikan anak-anak. Hal ini dilakukan sebagai perlawanan kontra produktif terhadap kurangnya perhatikan pihak gereja di bidang pendidikan, ditandai degan anak-anak sering tidak diperbolehkan bersekolah tetapi bekerja keras mencari nafkah untuk memenuhi kebutuhan hidup. Selain bekerja, banyak dari antara anak-anak hidup gelandangan sehingga Raikes mengumpulkan anak-anak pada hari Minggu, diajar membaca, menulis dan berhitung, menjadi salah satu cara untuk memperbaiki nasib anak-anak gelandangan dan anak-anak yang dipekerjakan di bawah umur, sehingga memperkuat kemauan Raikes mempercepat usaha mengumpulkan anak-anak pada hari Minggu sore di sebuah dapur kecil milik Meredith di kota Scooty Alley dan merupakan lembaga pertama sekolah minggu yang tidak hanya dipergunakan untuk belajar membaca dan menulis, termasuk di dalamnya mempelajari Firman Tuhan.

Anak-anak bekerja membutuhi nafkah termasuk anak-anak gelandangan dibujuk mengikuti sekolah minggu sesuai jadwal dilaksanakan pada pukul 14.0017.00. Pada waktu tersebut diajarkan pengetahuan membaca, menulis, berhitung, tata cara hidup berdasarkan ajaran-ajaran Alkitab. Pada mulanya sekolah minggu dilakukan atas prakarsa Raikes, dan disosialisasikan melalui tulisan di dalam terbitan harian (Koran), akhirnya pekerjaan ini diminati oleh sebahagian masyarakat Inggris. Dalam kurun waktu 4 tahun jumlah anak-anak hadir mengikuti kegiatan Sekolah Minggu sangat pesat mencapai 250.000 anak di seluruh Inggris .Ketika Robert Raikes meninggal dunia pada tahun 1811, jumlah anak mengikuti kegiatan Sekolah Minggu di seluruh Inggris mencapai lebih dari 400.000 orang. Gerakan di Inggris akhirnya menyebar ke berbagai belahan dunia, termasuk negara-negara Eropa lainnya dan Amerika.

Permulaan abad ke-20 zending-zending mendirikan sekolah untuk anakanak sekaligus sebagai tempat kebaktian. Ada beberapa buku pedoman mengajar anak diterbitkan oleh para missionaris/zending. Perkembangan selanjutnya dipersiapkan oleh Dewan Gereja Indonesia (sekarang PGI) dibentuk "Seksi Sekolah Minggu sementara" dan disahkan pada tahun 1953. Pada tahun 1953 dikenal permulaan koordinasi bersifat pribumi disponsori oleh Dewan Gereja Indonesia dalam organisasi DGI membentuk suatu seksi dinamakan Seksi Sekolah Minggu. Pada masa itu diberi status sementara, selanjutnya disahkan menjadi seksi tetap diberi tanggungjawab sebagai berikut: menerbitkan 
kurikulum, mengadakan pelatikan guru sekolah minggu, dan berinisiatif untuk menyelidiki ilmu jiwa anak Indonesia sebagai salah satu pendukung melaksanakan pembelajaran anak Sekolah Minggu di seluruh gereja anggota DGI. Pengertian Profesi Guru menurut Undang-Undang Nomor 14 Tahun 2005 terdiri dari: 1. Guru adalah pendidik profesional, 2. Memiliki kualifikasi akademik, 3. Memiliki kompetensi melaksanakan tugas profesional, 4. Lulus sertifikasi pendidik sebagai pengakuan kepada guru sebagai tenaga professional sedangkan pengertian Guru menurut peraturan Menteri Pendidikan Nasional adalah pendidik profesional, memiliki kualifikasi akademik, memiliki kompetensi, dan sertifikat pendidik.

Sejak Perjanjian Lama, Allah telah mengingatkan pentingnya pendidikan bagi anak-anak. Sejalan dengan itu, Musa mengingatkan hal ini kepada para orang tua dengan mengatakan: "Tetapi waspadalah dan berhati-hatilah, supaya jangan melupakan hal-hal yang dilihat oleh mata sendiri, dan supaya jangan semuanya itu hilang dari ingatan seumur hidup. Beritahukanlah kepada anak-anak dan kepada cucu cicit semuanya itu." (Ulangan 4:9) "sebagaimana telah diperintahkan Allah, pada hari ini haruslah diperhatikan, haruslah mengajarkannya berulang-ulang kepada anak-anak dan membicarakannya apabila duduk di rumah, apabila sedang dalam perjalanan, ketika berbaring dan pada waktu setelah bangun. Haruslah juga mengikatkannya sebagai tanda pada tangan, dan haruslah itu menjadi lambang di dahi, dan haruslah engkau menuliskannya pada tiang pintu rumah dan pada pintu gerbang." (Ulangan 6:6-9).

\section{A.Pendidikan dan Masa Depan}

Hamilton mengatakan: "Sebagai lembaga, gereja dan keluarga Kristen berkaitan erat antara satu dengan lain seperti bayi kembar siam; jika keduanya dipisahkan, akan memotong suatu nadi kehidupan, dapat menyebabkan salah satu atau keduanya menghilang (mati). Gereja tidak dapat berfungsi sebagaimana mestinya di tengah dunia yang kacau ini, kecuali jika gereja "mempekerjakan" keluarga sebagai pihak utama yang dapat dipercaya dalam pemeliharaan Kekristenan. Hamilton berkeyakinan bahwa keluarga tidak dapat menjadi sebuah keluarga Kristen atau keluarga bahagia kecuali jika tetap tinggal dalam sirkulasi pengaruh rohani yang hanya dihasilkan paling besar oleh gereja."

Bagi gereja, nilai-nilai luhur sengaja diajarkan mewujudkan kebenaran spiritual bersumber dari Firman Tuhan. Pendidikan rohani sebaiknya dilakukan sedini mungkin untuk menjaga hidup individu, seperti yang ditulis dalam Ulangan 32:47, "... sebab perkataan ini bukanlah perkataan hampa, tetapi itulah hidup dan dengan perkataan ini akan lanjut umur, kemana pun pergi, menyeberangi sungai Yordan untuk mendudukinya." Potensi anak sebagai generasi mendatang tertulis dalam Alkitab. Allah memiliki maksud memberi perintah untuk mendidik orang 
muda (anak-anak). Allah menaruh kepercayaan dalam diri anak untuk terlibat dalam rencana yakni anak lugu belum mengetahui tentang kebaikan dan kejahatan (Ulangan 1:39). Selain dari hasil penelitian di atas, dikemukakan hasil penelitian Barna Research dalam kasus berbeda-beda. Survei dilakukan terhadap 1003 orang dewasa melalui wawancara di telepon pada bulan November 2001, menunjukkan dari sejumlah 771 orang masih setia hadir di gereja (Barna Research, Mei 2001), termasuk "anak Sekolah Minggu mengikuti kegiatan pada hari minggu. Kesetiaan seperti itu memperlihatkan benefit dimulai sejak masa kecil memberikan dampak seumur hidup (adult who attended church as children show lifelong effect). " Hasil penelitian ini menjadi masukan bagi umat Kristen, bahkan bagi guru sekolah minggu untuk menguatkan semangat, betapa perlunya mendidik anak-anak pada Sekolah Minggu.

\section{B. Anak-Anak Masa Depan Gereja}

Martha Christianti menyatakan bahwa memahami anak didik dapat dilakukan dengan mempelajari karakter, kebutuhan dan tahapan perkembangan usia anak. Hal ini sangat berpengaruh terhadap pemilihan dan penetapan strategi kegiatan guru di Sekolah Minggu. Jika kegiatan yang dipilih terlalu tinggi tingkat kesulitannya maka anak sulit untuk menangkap tujuan kegiatan tersebut, demikian pula sebaliknya. Berikut ini ada beberapa hal yang penting masukan dari psikologi anak, perlu dipelajari dan dipahami sebagai dasar pelayanan. 1. Kebutuhan dasar anak: Anak membutuhkan kualitas primer dan kesunder, kasih sayang, rasa aman, cinta kasih, disiplin (untuk menahan diri), kebebasan yang wajar, membutuhkan penghargaan, penanaman nilai-nilai, dan lain-lain. Kebutuhan ini disebut kebutuhan dasar memperlengkapi anak-anak oleh orangtua dan guru Sekolah Minggu. 2. Prinsip Mendidik Anak Sekolah Minggu: a). Semua pengalaman anak dapat mempengaruhi membentuk watak dan mengarahkan jalan hidup; sebagaimana diungkapkan oleh Dorothy Law Nolte: Jika anak hidup dengan kritikan, cenderung belajar menghakimi. Jika seorang anak hidup dalam kebencian, cenderung belajar tentang kejahatan. Jika seorang anak hidup dengan ejekan, cenderung belajar menjadi malu. Jika seorang anak dipermalukan, cenderung belajar merasa bersalah. Jika seorang anak hidup dengan dorongan, cenderung belajar percaya diri. Jika seorang anak hidup dengan pujian, cenderung belajar menghargai. Jika seorang anak hidup dengan keadilan, cenderung belajar keadilan. Jika seorang anak hidup dengan aman, cenderung belajar nyaman. b). Kepribadian anak mudah dibentuk pada usia dini. c). Setiap tahap perkembangan anak membutuhkan pembinaan khusus. d). Seorang anak sedang menunggu untuk diisi oleh orang dewasa dalam berbagai bentuk. 


\section{C.Peran Guru Sekolah Minggu}

Hingga saat ini Sekolah Minggu masih membutuhkan revitalisasi mulai dari definisi, jalur, jenjang, jenis, bentuk, struktur, kurikulum, standar pengeloalaan, penjaminan mutu, persyaratakan komptesnsi, dan lain-lain. Walaupun belum mempersyaratkan keempat kompetensi kepada guru sekolah minggu, namun diberi tanggungjawab mendidik dan mengajar anak-anak gereja mempunyai tugas dan panggilan guru Sekolah Minggu untuk: 1). Mengajar ( I Timotius 2: 7) menjadi tugas guru sekolah minggu menyampaikan pokok-pokok iman mendasari kehidupan kekristenan. 2). Memberikan teladan ( I Kor.11:1; Filipi 3: 7; I Tim. 4: 11-13) mempersyaratkan guru sekolah minggu berpengaruh luar biasa terhadap murid untuk ditiru atau dicontoh/diteladani setiap anak sekolah minggu baik perbuatan, tutur kata mapun tingkah laku gurunya. Oleh sebab itu, guru sekolah minggu perlu selalu memperhatikan dirinya sendiri apakah sudah benar menjadi teladan bagi murid-murid; baik ketika berada di dalam kelas maupun di luar ruangan Sekolah Minggu. 3). Menginjil (I Timotius 2: 7) disinergitaskan dengan mengajar, penginjilan tidak hanya menyampaikan kebenaran iman kristen, tetapi juga memberitakan (versi pembelajaran) kabar baik bahwa Allah mengasihi manusia supaya jiwa anak-anak diselamatkan menjadi dasar melekat antara penginjilan dan pembelajaran. 4). Mendoakan (II Timotius 1: 11-12), doa merupakan nafas kehidupan umat Kristen, mendoakan anak-anak dan keluarganya merupakan bagian penting yang harus dilakukan oleh seorang guru sekolah minggu untuk menjalin komunikasi antara Tuhan dengan keakraban bersamasama anak Sekolah Minggu dan orangtua. 5). Menggembalakan (Yehezkiel 34:26; Yohanes 10:11-18) mempersyaratkan guru sekolah minggu tidak hanya pengajar tetapi juga mengembalakan anak Sekolah Minggu.

Berdasarkan nats Alkitab di atas, setiap guru Sekolah Minggu memiliki pola hubungan dan kerja sama sebagai syarat sebelum mengelola pembelajaran anak Sekolah Minggu meliputi, antara lain: 1). Memiliki hubungan pribadi dengan Tuhan. Panggilan Tuhan kepada setiap jiwa pendidik dianggap cukup menjadi jawaban dari serangkaian tugas melakukan pendidikan dan pembelajaran karena pada umumnya rekruitmen guru Sekolah Minggu tanpa dilatarbelakangi pendidikan akademik profesional menjadi syarat menjadi guru Sekolah Minggu. Seakan-akan cukup bersyarat bagi guru sekolah minggu hanya memiliki sikap dan keteguhan iman, sekoyong-konyong kembali pada pada tahun 70 melakukan rekruitmen guru Pendidikan Agama Kristen (PAK) berlatar belakang sintua/pertua/ diaken/pengurus gereja tanpa civil effec akademik profesional diberi tanggung jawab mengelola kegiatan pembelajaran secara hakiki melakukan peristiwa besar dari serangkaian rencana keselamatan telah, sedang dan akan dikerjakan oleh Allah melalui Tuhan Yesus Kristus. 2). Hubungan Guru dengan anak sekolah minggu. Dikaji berfdasarkan peran pendidik pada masa kini, 
memberi tanggung jawab penuh kepada setiap guru sekolah minggu, bahkan dipercayakan mengelola serangkaian kegiatan pembelajaran berfasarkan fakta keadaan di lingkungan pendidikan dan pembelajaran anak-anak Sekolah Minggu, diuraikan sebagai berikut: a). Mendoakan anak sekolah minggu. Tidak cukup jikalau guru hanya menyiapkan pelajaran dan mengajarkannya tanpa doa, sebaiknya pembelajaran itu dilengkapi dengan permintaan doa, hal ini dapat dilakukan apabila diperlengkapi dan bersama-sama dengan Roh Tuhan, tentu mengharapkan hasil belajar lebih baik dan berkualitas. Lebih jauh dari pada itu, guru mendoakan seluruh anak setiap saat, seraya menjalankan tugas sebagai agen pembaharuan melalui transmisi, memanfaatkan kesempatan gemilang untuk memohon di hadapan takhta anugerah Allah menerima segala keperluan rohani untuk mendidik dan mengajar para murid sekolah minggu (Mark. 11:17, Mark. 11:17). b). Menasihati anak sekolah minggu. Nasehat biasanya berhubungan dengan taksonomi afektif, guru berusaha memberi nasehat sebagai sahabat setia setiap anak sekolah minggu, pada pihak lain, memberi bimbingan dan arahan untuk keperluan persahabatan dalam bentuk pembinaan seirama dengan fase usia dan sesuai dengan latar belakang anak Sekolah Minggu. Untuk mencapai maksud tersebut, setiap guru memerlukan informasi tentang karakteristik anak sekolah minggu agar dapat melakukan pembimbingan lebih relevan, efisien dan efektif. 3). Hubungan pribadi dengan gereja.

Guru sekolah minggu tidak terpisahkan, bahkan agen pembaharuan melaksanakan kegiatan pembinaan berencana dan berprogram sesuai kebutuhan gereja terhadap warga jemaatnya. Oleh sebab itu, setiap guru sekolah minggu hendaknya memahami dan mengaplikasikan apa yang menjadi visi dan misi gereja dalam konteks sekolah minggu. Setiap program dan kegiatan disesuaikan dengan kebijakan gereja. a. Menceritakan isi Alkitab. 1). Guru berkewajiban mengenal cerita, percaya akan kebenaran cerita, harus menghargai cerita, mencerita bukan hanya mendongeng, cerita disampaikan dengan hidup. Mulailah cerita itu dengan pendahuluan kemudian isi sampai ketitik kesimpulan. Usahakan suara merdu, keras, lembut, menyakitkan dan lain-lain. Tetapi jangan lupa menyesuaikan suara itu sesuai dengan suka-duka cerita yang disuguhkan, cerita tidak membosankan anak-anak, pakailah kata-kata yang teratur tanpa bertele-tele. 2). Cerita menggugah perasaan hati anak-anak. Bercerita kepada anak-anak hendaknya seperti menyaksikan peristiwa yang sedang terjadi. Usahakanlah menggambarkan peristiwa itu setepat mungkin dengan gerak-gerik, dan dengan nada suara yang sesuai dengan suka duka cerita. Mungkin suara ketika menyajikan cerita itu perlu bersemangat keras dan lembut, lambat atau cepat, gerak badan dan air muka kesemuanya menyesuaikan diri dengan isi cerita. Mimik harus mengikuti suka duka cerita. b. Nyanyian rohani. 1). Arti nyanyian rohani. Nyanyian adalah bunyi yang diucapkan menurut nada dan irama tertentu 
yang mempunyai sesuatu arti makna dan prinsip. Bernyanyi bukanlah hal yang baru dikenal, melainkan sudah dimulai dari Perjanjian Lama (PL). Pemazmur mengiringi nyanyian dengan musik (ingat raja Daud seorang tukang musik). Demikian juga dapat dilihat dari sudut kitab Mazmur, dari sana dapat diketahui bahwa pada tahun \pm 100 BC kitab itu sudah selesai dikumpulkan menjadi satu kitab ${ }^{2)}$. Menyajikan nyanyian rohani. Ada nyanyian rohani yang belum cocok dengan fase-fase perkembangan anak atau tidak sesuai dengan tingkat kematangan anak-anak misalnya nyanyian tentang Trinitas dan Christologi, karena yang ditonjolkan di sana adalah hubungan Keallahan, hal itu tidak sesuai dengan perkembangan atau tingkat kematangan anak-anak, karena daya serap/cara berfikir anak-anak belum mampu menelaah isi nyanyian rohani tersebut. c. Berdoa. Berdoa ialah berhubungan langsung dengan Tuhan atau berbicara, berdialog atau bercakap-cakap dengan Tuhan. Sebagaimana anak kecil berhubungan langsung dengan orang tuanya, dan sebaliknya orang tua berhubungan langsung dengan anak-anaknya. Demikian jugalah Bapa di Surga dapat berbicara, berdialog dan bercakap-cakap terhadap orang-orang percaya. Doa dapat diucapkan dalam bentuk : permohonan, ucapan syukur, pengampunan dosa, perlindungan, penyerahan diri, pujian, pengakuan .dosa, jawaban atas doa yang terkabul, doa pengharapan. 1). Mengajar Anak mengenal Alkitab a). Mengenal huruf/angka Alkitab. Kegiatan pembelajaran Sekolah Minggu yang diprakarsai oleh Robert Raikes terdiri dari tiga yakni: membaca, menulis dan berhitung, menginsiasi salah satu dari antaranya membelajarkan kanak-kanak yang belum tahu membaca. Kegiatan pembelajaran mengenal huruf Alkitab kurang diminati gereja untuk melatih kanak-kanak pra sekolah, pihak gereja secara umum belum memberi perhatian kepada kanak-kanak pra sekolah dan anak-anak untuk melafalkan huruf huruf/angka-angka dan gabungan huruf dan angka menjadi frasa sebagaimana tertulis di dalam Alkitab. b). Mengabjad. Mengabjad nats atau ayatayat Alkitab dan menghafal hingga fasih perlu diajarkan kepada anak-anak, tidak cukup hanya pada waktu natal menyebutkan isi nats Alkitab di atas altar bagian dalam gereja. Misalnya mengabjat nama; Y-e-s-s-u-s dilanjutkan dengan penggabungan kata; Ye-sus sehingga menjadi satu kata; Yesus, bahkan secara step wajib dikembangkan menjadi frasa, misalnya; Yesus Kristus. Membiasakan anak sekolah minggu akrab dengan Alkitab sejak dini dan mengharapkan pada masa yang akan datang memiliki kemampuan dibarengi dengan kemauan yang tinggi untuk membaca Alkitab secara rutin. Sesuai dengan kitab Ulangan 6:7-9 dapat dilakukan secara berulang ulang hingga anak sekolah minggu fasih mengabjat nas Alkitab yang dibutuhkan. c). Menulis. Yesus sebagai guru mengingatkan tulisan pada kitab Yohanes: Musa menuliskan tentang Yesus, Yesus menulis di tanah, tentang Yohanes di batu tulis, menulis Raja orang Yahudi, murid menulis kesaksian, membaca sumber belajar tertulis tentang Nabi, kesahihan saksi-saksi, Kitab Musa dan nabi-nabi sebagai sumber tertulis. 2). 
Menghafal ayat emas pendek. Pembacaan hafalan, hafalan yang diucapkan oleh murid-murid di dalam kelas, sedangkan hafalan diartikan dengan: yang dihafalkan, hasil menghafal Setiap peserta didik sangat akrab dengan hafalan dan tidak ubahnya dengan menghafal ayat emas sesuai dengan karakteristik anak sekolah minggu.

\section{KESIMPULAN}

Berdasarkan penjelasan tersebut di atas, dapat disimpulkan bahwa menjadi guru sekolah minggu yang ideal pada dasarnya menjadi pendidik yang dapat dipercaya, seperti dikatakan Paulus dalam I Korintus 4: 1-2. Dipercaya oleh Tuhan, anak-anak, orangtua anak, rekan sepelayanan dan gereja. Sebagai manusia memang tidak ada yang sempurna. Tetapi, bukankah salah satu panggilan Tuhan agar berusaha terus memacu dan mempersiapkan diri agar setiap hari semakin sempurna di hadapan-Nya (bdk. Matius 5: 48). Sebaiknya setiap menjadi teladan yang kuat berpengaruh mempersatukan kata dan perbuatan dari dalam diri setiap guru sekolah minggu, untuk selanjutnya ditiru anak-anak sekolah minggu. Pengelolaan Sekolah Minggu membutuhkan pertimbangan khusus menentukan jalur, jenjang, jenis dan bentuk termasuk mempersiapkan tenaga profesional, memiliki kualifikasi akademik, memiliki kompetensi, dan sertifikat pendidik sesuai dengan ketentuan peraturan perundang-undangan, namun tidak bertentangan dengan acuan norma kanonik. Pertimbangan spesifik perlu dilakukan dalam rangka mempersiapkan kualitas sumber daya gereja Kristen sejak dini agar tidak tertinggal dari kualitas sumber daya manusia di Indonesia, bahkan kualitas bangsa-bangsa di belahan dunia.

\section{DAFTAR PUSTAKA}

Baker L. David (1986). Mari Mengenal Perjanjian Lama, BPK Gunung Mulia. Blomendal (1998), Pengantar ke Dalam Perjanjian Lama, BPK Gunung Mulia, Jakarta

Lautfer Ruth \& Dyck Anni (1993). Pedoman Pelayanan Anak 2, Yayasan Persekutuan Pekabaran Injil Indonesia, Malang

Rohani Ahmad, HM., M.Pd., (1997). Media Instruksional Edukatif, Jakarta: Rineka Cipta.

Shamsudin (1997), Republika, 25 Nopember 1997.

White G. Ellen (2005). Membina Anak yang Bertanggungjawab. Bandung: Indonesia Publishing House.

-------Alkitab Perjanjian Lama dan Perjanjian Baru, terjemahan Lembaga Alkitab Indonesia (LAI)

-------Surat Edaran (SE) Mendikbud dan Kepala BAKN No. 57686/MPK/1989.

-------Undang-Undang Nomor 14 Tahun 2005 tentang Guru dan Dosen.

$\mathbf{3 8}$ | Tugas dan tanggungjawab guru sekolah minggu........ Simatupang, Hasudungan

Jurnal Christian Humanioran | http://e-journal.iakntarutung.ac.id/index.php/humaniora 
-Peraturan Mendiknas Nomor 16 Tahun 2007.

-Peraturan Pemerintah RI Nomor 55 Tahun 2007, tanggal 5 Oktober 2007

Tentang Pendidikan Agama Dan Pendidikan Keagamaan.

http://alkitab.sabda.org/resource.php?topic=724\&res=jpz;

http://www.gkpb.net/artikel-menu/teologi/item/831-tanggung-jawab-orang-tua-

dan-gereja-dalam-pendidikan-anak;

http://kamusbahasaindonesia.org/Resitasi\#ixzz2FZPIi1zL.

http://kamusbahasaindonesia.org/hafalan\%20\#ixzz2FZWSQQtD.

http://www.worldbank.org/in/news/feature/2012/06/13/indonesia-development-

of-the-young-helps-development-of-a-country0

http://www.gkpb.net/index.php?option=com_k2\&view=item\&id=831:tanggung-

jawab-orang-tua-dan-gereja-dalam-pendidikan-anak \&Itemid=381

http://pepak.sabda.org/tanggung_jawab_orang_tua_dan_gereja_dalam_pendidika

n_anak

http://www.pengertiandefinisi.com/2011/11/pengertian-guru.html.

http://id.wikipedia.org/wiki/Guru.

https://sites.google.com/a/gkihalimun.org/gereja-kristen-indonesia-

halimun/kegiatan-pembangunan-jemaat/artikel-bina-

iman/sekolahminggudangurusekolahminggu

http://id.wikipedia.org/wiki/Sekolah_Minggu 